\title{
A Cross-sectional Study on the Self-Efficacy of Pre- service Science and Mathematics Teachers in a Philippine State University
}

\author{
Ma. Rachel Kim L. Aure and Richard R. Jugar \\ Department of Teacher Education Visayas State University Leyte, Philippines \\ and Science and Mathematics Education Department University of San Carlos Cebu \\ City, Philippines
}

\section{ABSTRACT}

This study investigated the self-efficacy levels of pre-service science and mathematics teachers in a Philippine state university. A total of 172 pre-service science and mathematics teachers served as respondents of the study. Data collection was done through the use of the Science and Mathematics Teaching Efficacy Belief Instrument for Pre-service Teachers. The ANOVA indicated significant difference self-efficacy according to year level such that fourth year pre-service teachers indicated a statistically significant decrease. No significant difference was observed for gender and specialization. As regards to the type of courses as predictors of selfefficacy level, general education courses showed low positive predictive power $(\beta=0.180)$ whereas specialization courses and professional education courses showed a negative predictive power of $\beta=-0.198$ and $\beta=$ -0.702 respectively. General education and professional education courses displayed significant predictive power at $\mathrm{p}<0.05$ whereas specialization courses did not $(\mathrm{p}=0.151)$. The overall explanatory power of the regression model was $61.1 \%\left(\mathrm{R}^{2}=0.611, \mathrm{~F}(3,171)=90.419, \mathrm{p}<0.001\right)$. The implications on the teacher education preparation as well as for future directions are likewise discussed.

Key words: pre-service, science and mathematics education, self-efficacy, teacher preparation

\section{INTRODUCTION}

The newly-initiated Philippine educational reform grounded on Republic Act 10533 or the Enhanced Basic Education Act of 2013 has the main goal of improving the educational qualification of Philippine graduates through the provision of relevant programs that are deemed at par with international standards (Department of Education 2012). While the reform focuses in the basic education level, most notably the addition of two more years of secondary education, it is but expected that the said

Correspondence: Ma. Rachel Kim L. Aure Address: Department of Teacher Education, Visayas State University, Visca, Baybay City, Leyte. Philippines E-mail:kim_aure@vsu.edu.ph DOI: 10.32945/atr3919.2017 
reform will have a cascading effect on higher education. This effect is very evident in the current movements in higher education such as changes in accreditation process, new typologies, adoption of outcome-based education (OBE) and re-standardization of curricular program offerings, among others. Anticipating the changes associated with this educational reform, the current study focused on the teacher education program of a particular state university, with self-efficacy as the construct of interest. The main objective of the study was to determine the level of self-efficacy of science and mathematics teachers as they progressed from one year level to another in a typical teacher education program of a Philippine teacher education institution (TEI). Moreover, this study also aimed to contribute to existing literature on self-efficacy of science and mathematics teacher education in Philippine and to establish a baseline data of science and mathematics teachers' self-efficacy prior to the full implementation of the Philippine Educational Reform.

Teacher Education Program in the Philippines

Teacher education in the Philippines is a four-year bachelor curricular program offered by TEIs, which could be a state university or college (SUC) or a private institution. As a curricular program in higher education, teacher education falls under the jurisdiction of the Commission on Higher Education (CHED). Moreover, since teacher education is considered as a professional program, the Professional Regulation Commission (PRC) of the Philippines is likewise involved in its regulation, specifically in the conduct of the Licensure Examination for Teachers (LET).

Currently, the teacher education program is governed by CHED Memorandum Order 30 (CMO 30) or the Revised Policies and Standards for Undergraduate Teacher Education Curriculum (2004). Stipulated in the memorandum are two distinct teacher education program offerings namely Bachelor of Elementary Education (BEEd) and Bachelor of Secondary Education (BSEd). The BEEd program is structured to meet the needs of professional teachers for elementary schools and is aimed to develop teachers who can teach across the different learning areas in grade school (generalists). The BEEd program likewise includes special education and pre-school teachers. The BSEd program on the other hand aims to develop discipline-based teachers who can teach in the different learning areas in high school such as Science, Mathematics, etc. It has to be noted that CMO 30 was contextually developed to address the then K-10 basic education program of the Philippines.

In terms of curricular content, CMO 30 specifies the distribution of courses in the teacher education program as summarized in Table 1. 
Table 1.Summary of courses for Philippine Teacher Education Program

\begin{tabular}{|c|c|c|c|}
\hline \multirow[t]{2}{*}{ Course Category } & \multicolumn{2}{|c|}{$\begin{array}{l}\text { Curricular } \\
\text { Program } \\
\text { and No. of Units } \\
\end{array}$} & \multirow[t]{2}{*}{ Description } \\
\hline & BEEd & BSEd & \\
\hline $\begin{array}{l}\text { General Education } \\
\text { Courses }\end{array}$ & 63 & 63 & $\begin{array}{l}\text { Group of courses composed of language and } \\
\text { literature, mathematics and natural sciences } \\
\text { and mandated courses to be taken by } \\
\text { students in higher education pursuing a } \\
\text { year bachelor's degree }\end{array}$ \\
\hline $\begin{array}{l}\text { Professional } \\
\text { Education Courses }\end{array}$ & 54 & 51 & $\begin{array}{l}\text { Courses aimed to develop the range of } \\
\text { knowledge and skills needed in the practice } \\
\text { of teaching profession that include theory } \\
\text { and concept courses, methods and } \\
\text { strategies courses, field studies and special } \\
\text { topics }\end{array}$ \\
\hline $\begin{array}{l}\text { Specialization/Conte } \\
\text { nt Courses }\end{array}$ & 57 & 60 & $\begin{array}{l}\text { Courses aimed to develop content } \\
\text { knowledge in an identified area of } \\
\text { specialization }\end{array}$ \\
\hline $\begin{array}{l}\text { Total Number of } \\
\text { Units }\end{array}$ & 174 & 174 & \\
\hline
\end{tabular}

The purpose of CMO 30 is to provide a framework for TEI's in constructing their curriculum for their respective teacher education program offerings. It is also important to note that while majority of the general education courses are taken in the first year of the teacher education curriculum, the distribution of content or specialization courses and professional education courses differs from one institution to another. Further, while it may be observed that the sequence of course offerings in both professional education and content courses follows a definite hierarchy, students take these courses together at any given semester. In effect, a teacher education student generally enrols in a mixture of content and professional education courses in a given semester. Some students have general education courses on top of their usual professional and content courses. This practice poses one unavoidable limitation in this study since we purposively treated the different course categories as though they were taken together as one category at a time to determine the respective categories' effect on the self-efficacy of pre-service science and mathematics teachers.

\section{The Construct of Self-Efficacy}

The arrangement and line-up of courses in a typical Philippine teacher education curriculum constitutes the academic experience of pre-service teachers. As the year-level of a pre-service science and mathematics teacher increases, it is likewise assumed that he or she has also acquired growth both in skills and content of the teaching profession. In this study, 
such assumed growth of a teacher education student in the context of his or her university academic experience is represented by the construct of selfefficacy. Specifically, the study aimed to quantitatively capture the development of self-efficacy levels of science and mathematics teachers as they progress from one year level to another as well as to ascertain if the completion of the typologized types of courses contributed to the selfefficacy levels of the respondents.

Self-efficacy is widely acknowledged as an important aspect of human motivation that in turn influences choices and actions. Bandura (1995) explains that self-efficacy "refers to beliefs in one's capabilities to organize and execute the courses of action required to manage prospective situations." In effect, self-efficacy simply refers to the belief of an individual on his or her ability to complete a task. In the study, the construct of selfefficacy was contextualized in the teaching of science and mathematics by pre-service teachers.

Bandura (1977) outlined four sources of self-efficacy information as outlined by Bandura (1977) that enable individuals to judge their selfefficacy levels: performance outcomes, vicarious experiences, verbal persuasion and physiological feedback. Performance outcomes refer to the collective negative and positive experiences of the individual in accomplishing a certain task. This particular source is also deemed to be the strongest and the most important of all sources. Vicarious experiences refers to the experience of individual observing or "benchmarking" from the performance of other people in the same identified task. Verbal persuasion refers to the encouragement or discouragement input of the surrounding people to the individuals' performance of a given task. Lastly, physiological feedback is defined as the environmental stimulus that the individual receives or perceives in performing a given task. Collectively, these four may be accessed by the individual simultaneously at varying degrees. In this study, these four sources of judging self-efficacy were assumed to be subsumed in the university academic experience of preservice science and mathematics teachers. While teacher self-efficacy is also influenced by personality and belief orientation (Jamil, Downer \& Pianta 2012), such factor is not taken into account in the current study since it is understood that teacher preparation program should be able to develop capable and competent teachers regardless of their personality and individual beliefs.

Self-efficacy as a construct is important because it influences attrition rate among service teachers. Novice teachers with a higher sense of selfefficacy tend to persist and stay longer in the teaching profession (Knobloch \& Whittington 2002). Also, there is a positive correlation between self-efficacy and the teachers' persistence and resilience in the field of teaching profession (Yost 2006). 
Course Typology and Self-Efficacy

This study utilizes the typology provided by the Commission on Higher Education (CMO 30 2004) for the teacher preparation program as offered by Philippine TEI's. As presented in Table 1, the courses are categorized as general education courses, professional education courses and specialization or content courses. The assumption of the study is that such typology contributes to the perceived self-efficacy of pre-service teachers as contextualized in science and mathematics teaching. Apart from the identification of a baseline data for pre-service science and mathematics teachers' efficacy, the current study likewise aims to determine whether the typologized courses as measured in terms of number of equivalent academic units taken, do contribute to the self-efficacy levels of the respondents. The treatment of academic sources as typologized is justified since each category actually develops a certain aspect of the teacher.

A number of studies across different types of courses (e.g. method, content) are available in several literature. In one study, it was found out that self-efficacy is influenced by mastery experiences, vicarious experiences, physiological and affective states as well as prior beliefs and experiences of science. Most notably, efficacy for science teaching is enhanced through particular aspects of the teaching context such as opportunities for collaboration and successful participation in science teaching practice (Mansfield \& Woods-McConney 2012). A study exploring whether teachers' self-efficacy may be increased through content-specific knowledge with pedagogical emphasis with calculus as the vehicle of context was also conducted. It was found out that content knowledge training increases self-efficacy of teachers' outcome efficacy but not personal efficacy (Swackhamer et al 2009).The relationship between academic self-efficacy and teacher self-efficacy belief was found out to be relatively direct. That is, teacher who indicate higher scores in academic self-efficacy tend to indicate equally higher scores in almost all aspects of the teacher self-efficacy belief (Tabancali \& Celik 2013). In another study, results showed that mathematics teachers who pose higher self-efficacy beliefs tend to possess more sophisticated belief as well as elevated confidence in problem solving. Moreover, it was found out that mathematical beliefs have a significant effect on mathematical efficacy as well as mathematical teaching efficacy (Briley 2012).

Self-efficacy when treated as a main construct could also be described in terms of relevant domains. In one study, self-efficacy belief level of novice teachers was found to be relatively adequate. It was further found out that novice teachers indicated highest efficacy belief in the use of teaching strategies in class, followed by classroom management and finally student engagement (Ozder 2011). In another study conducted among science teachers, it was established that the confidence self-efficacy belief of physical science teachers were higher in established science concepts as compared to newer industrial applications (Lekhu 2013). Based on the 
findings of the aforesaid relevant empirical researches, it is evident that different academic experiences afford different influence on self-efficacy as a construct as well as differing effects on its identified relevant domains. In the context of this study, the academic experience of pre-service science and mathematics teachers were typologized based on the courses that they have taken, which in principle is supposed to afford them different learning experiences.

To reiterate, the study sought to accomplish the following objectives: (a) identify the self-efficacy levels of pre-service science and mathematics teachers with respect to gender, specialization and year level; and (b) identify which type of courses predict self-efficacy levels of fourth year preservice science and mathematics teachers.

\section{METHODOLOGY}

The study utilized survey as the main method of data acquisition. Given the nature of self-efficacy as a construct that can be best described by the respondent themselves, self-reported survey was deemed applicable and appropriate (Cunningham, Preacher \& Banaji 2001). The main research instrument used in the study was the Science Teaching Efficacy Belief Instrument-Pre-service originally developed by Enochs and Riggs (1990) and revalidated by Bleicher in 2004. Minor modification on the instrument was applied to accommodate mathematics teaching but with pending expressed permission from the original author. The study was conducted in one of the state universities in Eastern Visayas Region, Philippines. The science and mathematics teacher education program of the said university generally follows the CHED prescribed BSEd Curriculum. The research respondents were sophomore to junior university students enrolled in BSEd Mathematics, BSEd Physical Science and BSEd Biological Science. Transferees (student from other universities), shiftees (students previously enrolled from a different program) and irregulars (students who did not follow the prescribed number of units per semester as reflected in the program prospectus) were not included in the final list of the respondent count. All statistical treatments were processed utilizing the Statistical Package for the Social Sciences (SPSS v. 20).

\section{RESULTS AND DISCUSSION}

Table 2 describes the respondents who took part in the study in terms of year level, specialization and gender. The original number of respondents was $n=293$ but was reduced to $n=172$ after the removal of respondents who were categorized as shiftees, transferees and irregulars. Freshmen respondents were also removed since they did not have units in specialization courses. 
Table 2 shows the respondents distribution according to year level, specialization and gender. Around $70 \%$ of the respondents were science teachers, most of whom were specializing in biological sciences, with one in every 12 teachers who choose to specialize in biological sciences one opted to specialize in physical sciences. Almost $80 \%$ of the respondents were female.

Table 2. Respondent Distribution

\begin{tabular}{llccc}
\hline Category & Sub-Categories & Frequency & Percent & $\begin{array}{c}\text { Cumulative } \\
\text { Percent }\end{array}$ \\
\hline \multirow{4}{*}{ Year Level } & Second & 64 & 37.2 & 37.2 \\
\cline { 2 - 5 } & Third & 58 & 33.7 & 70.9 \\
\cline { 2 - 5 } & Fourth & 50 & 29.1 & 100.0 \\
\cline { 2 - 5 } & Total & 172 & 100.0 & \\
\hline \multirow{3}{*}{ Specialization } & Biological Sciences & 108 & 62.8 & 62.8 \\
\cline { 2 - 5 } & Mathematics & 55 & 32.0 & 94.8 \\
\cline { 2 - 5 } & Physical Sciences & 9 & 5.2 & 100.0 \\
\cline { 2 - 5 } & Total & 172 & 100.0 & \\
\hline \multirow{3}{*}{ Gender } & Male & 39 & 22.7 & 22.7 \\
\cline { 2 - 5 } & Female & 133 & 77.3 & 100.0 \\
\cline { 2 - 5 } & Total & 172 & 100.0 & \\
\hline
\end{tabular}

Self-Efficacy Levels Across Year Level, Specialization and Gender

The self-efficacy levels of the respondents across different year levels, specialization and gender are presented in Table 3, which shows the mean of summated self-efficacy levels and standard deviations.

Table 3. Summated Self-Efficacy Levels Across Groups

\begin{tabular}{llccc}
\hline Groups & Sub-groups & $\begin{array}{c}\text { Summated } \\
\text { Mean }\end{array}$ & $\begin{array}{c}\text { Standard } \\
\text { Deviation }\end{array}$ & $\begin{array}{c}\text { Mean Self- } \\
\text { Efficacy Level }\end{array}$ \\
\hline \multirow{3}{*}{ Year Level } & Second & 87.13 & 7.881 & 3.49 \\
\cline { 2 - 5 } & Third & 87.67 & 8.177 & 3.51 \\
\cline { 2 - 5 } & Fourth & 61.60 & 5.466 & 2.46 \\
\hline \multirow{3}{*}{ Specialization } & $\begin{array}{l}\text { Biological } \\
\text { Sciences }\end{array}$ & 80.81 & 13.219 & 3.23 \\
\cline { 2 - 5 } & Mathematics & 79.13 & 14.512 & 3.22 \\
\cline { 2 - 5 } & Physical & 73.56 & 15.930 & 2.94 \\
\hline \multirow{2}{*}{ Gender } & Sciences & 80.74 & 15.026 & 3.23 \\
\hline & Male & 79.64 & 13.475 & 3.19 \\
\hline
\end{tabular}

Self-efficacy level is relatively the same for second year and third year respondents. Fourth year students on the other hand shows relatively lower levels of self-efficacy as well as lower standard deviation indicative of consistency in their responses. There is also relative homogeneity of self-efficacy level with respect to gender. In terms of specialization, students majoring in physical sciences reported the least level of selfefficacy. 
In order to determine if a significant difference exists on the selfefficacy levels of the respondents when grouped according to year level, specialization and gender, ANOVA was employed.

Table 4. One-way Analysis of Variance of Perceived Self-Efficacy by Year Level

\begin{tabular}{lccccc}
\hline Source & $d f$ & SS & MS & $F$ & $p$ \\
\hline Between Groups & 2 & 23589.125 & 11794.563 & 221.629 & .000 \\
Within Groups & 169 & 8993.776 & 53.218 & & \\
Total & 171 & 32582.901 & & & \\
& & & & & \\
\hline
\end{tabular}

With respect to year level, there was a significant difference in the selfefficacy level among the respondents at $\mathrm{p}<.05(\mathrm{~F}(2,171)=221.629, \mathrm{p}<$ 0.01 ). Post hoc analysis using Tukey HSD revealed that the mean selfefficacy level of second years does not statistically differ with the mean self-efficacy level of third years ( $p=0.910)$. Both second and third year selfefficacy levels significantly differ with that of fourth year students $(\mathrm{p}<$ 0.001). Overall, results suggest that the self-efficacy levels of the preservice science and mathematics teachers generally change, that is - selfefficacy level becomes statistically significantly as they reach the last year level of their college preparation. This particular observation is consistent with the results of a study conducted to selected participants enrolled in a graduate diploma course where majority of the participants overestimated their teacher self-efficacy despite the fact that they have no actual or field experience such as when they are in their first year of university schooling. The study attributed such overestimation to the participants' positive schooling experience as a student and parental experience with their kids being sent to or going to school among others. In the subsequent measure following their immersion to the actual world of work, the participants rated themselves lower (Pendergast, Garvis \& Keogh 2011)

Table 5. One-way Analysis of Variance of Perceived Self-efficacy by Specialization

\begin{tabular}{lccccc}
\hline Comparison & $d f$ & SS & MS & $F$ & $p$ \\
\hline Between Groups & 2 & 483.653 & 241.827 & 1.273 & .283 \\
Within Groups & 169 & 32099.248 & 189.936 & & \\
Total & 171 & 32582.901 & & & \\
& & & & & \\
\hline
\end{tabular}


With regard to specialization, no significant difference was detected in the mean self-efficacy levels of the respondents when grouped according to specialization $(\mathrm{F}(2,171)=1.273, \mathrm{p}=0.283)$ as well as when grouped according to gender $(F(1,171)=0.192, p=0.662)$. The non-significant difference may be attributed to the relatively similar nature of science and mathematics as well as the relatively higher correlation of self-efficacy in mathematics and positive attitude towards science-based subjects (Betz \& Hackett 1983). The non-significant difference in the self-efficacy levels with respect to gender is consistent with the results of Ipek and Camadan (2012) as well as that of Mackay and Parkinson (2010) who found that attitude towards teaching may be associated with gender such that females generally exhibit higher or better attitude compared to their male counterparts.

Table 6. One-way Analysis of Variance of Perceived Self-Efficacy by Gender

\begin{tabular}{lccccc}
\hline & $d f$ & SS & MS & $F$ & $p$ \\
\hline Between Groups & 1 & 36.789 & 36.789 & .192 & .662 \\
Within Groups & 170 & 32546.113 & 191.448 & & \\
Total & 171 & 32582.901 & & & \\
\hline
\end{tabular}

Type of Course and Self-Efficacy Level

The current study takes into consideration the different types of courses taken by the respondents in their respective teacher preparation programs. Altogether, the number of units of professional education courses, specialization courses and general education courses are operationally defined as the university academic experience of the preservice science and mathematics teachers. Simple regression was employed to determine how the different types of courses predict the selfefficacy level of the respondents. Multi-collinearity analysis of independent factors was performed and yielded a variance inflation factor of 2.101 for general education courses, 6.666 for professional education courses and 8.295 for specialization courses while tolerance value of $0.497,0.150$ and 0.121 respectively. Independence of residuals was likewise analyzed and a Durbin-Watson value of 1.566 was obtained. Both tests for multi-collinearity and independence of residuals are well within the acceptable range of even the most conservative estimate for the regression to proceed (Hair, 2007). The result of the regression analysis indicated that the three types of courses explained $61.1 \%$ of the variance $\left(R^{2}=0.611, F(3,171)=90.419, p<0.001\right)$. In particular, general education 
courses $(\beta=0.180, p<0.009)$, professional education courses $(\beta=-0.702, p$ $<0.001$ ) were found to be significant predictors of self-efficacy, whereas specialization courses $(\beta=-0.198, p=0.151)$ was not.

The model clearly suggests that general education courses are positive predictors of self-efficacy whereas professional and specialization subjects tend to predict self-efficacy level negatively, albeit the predictive capacity of specialization courses is not significantat $p=0.05$. As the year level of the pre-service science and mathematics teacher respondents increases, it is imperative that the number of units taken in both professional and specialization courses have also increased; with general education courses assumed to be completed in the first two to four semesters (two years). As shown by the results of ANOVA and regression analyses, an increased number of units or courses taken in both professional education and specialization subjects (in effect, an increase in year level) decreased the self-efficacy level of the respondents. The contention of the current study is that as the content of the specialization courses deepens, the lessons associated with these specialization subjects likewise increases in difficulty thereby decreasing the self-efficacy of the pre-service teachers. The same reasoning is attributed to the negative predictive property of professional education courses. As the pre-service teachers are immersed in the different theories and practices of the teaching profession, they begin to see the demands, limitations as well as the inherent challenges of teaching that may have a decreasing effect in their self-efficacy levels.

Towards the end of their college preparation, pre-service teachers are given the chance to do practice teaching and it has been shown that practice teaching generally increases self-efficacy levels of pre-service teachers (Mackay \& Parkinson 2010). Moreover, self-efficacy dips on the first year of teaching and generally increases over time (Swan, Wolf \& Cano 2011).The study however did not include the pre-service science and mathematics teachers who have had completed their practice teaching experience. This limitation explains the lowest self-efficacy levels of the fourth year respondents.

\section{Conclusions and Implication for Future Studies}

The study attempted to determine the self-efficacy levels of science and mathematics pre-service teachers in a Philippine state university. Also, the typology of courses for teacher education programs as mandated by the Commission on Higher Education were also analyzed for their predictive power in influencing self-efficacy levels of pre-service teachers. The result of the study indicating a generally decreasing trend of self-efficacy levels as teachers' progresses in the number of years spent in TEI's. Wherein general education courses as positive predictors of self-efficacy and specialization and professional education courses as negative predictors of self-efficacy has implications in crafting the program of teacher education. 
Since self-efficacy levels decreased as more content (specialization) and knowledge of the teaching profession and its practices (professional education) is learned by the students, it is important that supportive interventions be undertaken to reinforce pre-service teachers' selfefficacy. These interventions should be done in the third and fourth years of the teacher-preparation program until just prior to practice teaching where pre-service teachers' self-efficacy levels tend to be lowest. Emphasis should be given to teachers who teach both specialization and professional education courses.

As described, the current study utilizes CMO 30 (2004) as its framework in determining the self-efficacy levels of pre-service science and mathematics teachers. The respondents of the study albeit sufficient for the purposes of the employed statistical treatments may not necessarily represent the entirety of the Philippine teacher preparation education landscape. Future studies may include multiple teacher education institutions to cover other relevant typologies such as sectarian or non-sectarian, private or state, and centers of excellence or development among others. Also, the explanatory power $\left(R^{2}=0.611\right)$ of the current study, while may be justified since the interest is on the predictive powers different types of courses, may still be improved to include other constructs that significantly predict self-efficacy levels.

\section{REFERENCES}

BANDURA, A. 1977. Self-efficacy: Toward a unifying theory of behavioral change. Psychological Review, 84(2), 191-215. doi:10.1037/0033295X.84.2.191

BANDURA, A. 1995. Exercise of personal and collective efficacy in changing societies. In A. Bandura (Ed.), Self-efficacy in changing societies (pp. 145). New York: Cambridge University Press.

BETZ, N. E., \& HACKETT, G. 1983. The relationship of mathematics selfefficacy expectations to the selection of science-based college majors. Journal of Vocational behavior, 23(3), 329-345.

BLEICHER, R. E. 2004. Revisiting the STEBI-B: Measuring self-efficacy in preservice elementary teachers. School Science and Mathematics, 104(8), 383-391.

BRILEY, J. S. 2012. The Relationships among Mathematics Teaching Efficacy, Mathematics Self-Efficacy, and Mathematical Beliefs for Elementary Pre-Service Teachers. Issues In The Undergraduate Mathematics Preparation OfSchool Teachers, 5

CUNNINGHAM, W., PREACHER, K., BANAJI, M. 2001. Implicit Attitude Measures: Consistency,Stability, and Convergent Validity. Psychological Science, v12(2), 163-170.

FINK, A. 2003. The Survey Handbook (2nd Ed.). London, Sage Publications.

GAY, L., MILLS, G., AIRASIAN, P. 2006. Educational Research: Competencies for Analysis andApplications (8th Ed). NJ: Upper Sadler River, Pearson. 
DEPARTMENT OF EDUCATION. 2012. The $\mathrm{K}$ to 12 Basic Education Program. Retrieved from http://www.gov.ph/k-12/

IPEK, C., \& CAMADAN, F. 2012. Primary teachers' and primary pre-service teachers' self-efficacy beliefs and attitudes toward teaching profession. International Journal OfHuman Sciences, 9(2), 1206-1216.

JAMIL, F. M., DOWNER, J. T., \& PIANTA, R. C. 2012. Association of Pre-Service Teachers' Performance, Personality, and Beliefs with Teacher SelfEfficacy at Program Completion. Teacher Education Quarterly, 39(4), 119-138.

KNOBLOCH, N. A., \& WHITTINGTON, M. S. 2002. Novice teachers' perception of support,teacher preparation quality, and student teaching experience related to teacher efficacy.Journal of Vocational Education Research, 27(3), 331-341.

LEKHU, M. (2013). Relationship Between Self-Efficacy Beliefs of Science Teachers and Their Confidence in Content Knowledge. Journal of Psychology In Africa, 23(1), 109-112.

MACKAY, J., \& PARKINSON, J. 2010. Gender, self-efficacy and achievement among South African Technology teacher trainees. Gender \& Education, 22(1), 87-103. doi:10.1080/09540250802467935

MANSFIELD, C. F., \& WOOD-McConney, A. 2012. "I Didn't Always Perceive Myself as a "Science Person"": Examining Efficacy for Primary Science Teaching. Australian Journal Of Teacher Education, 37(10),

OZDER, H. 2011. Self-Efficacy Beliefs of Novice Teachers and Their Performance in the Classroom. Australian Journal Of Teacher Education, 36(5), 1-15.

PENDERGAST, D., GARVIS, S., \& KEOGH, J. 2011. Pre-Service StudentTeacher Self-Efficacy Beliefs: An Insight into the Making of Teachers. Australian Journal Of Teacher Education, 36(12), 46-57.

SWACKHAMER, L., KOELLNER, K., BASILE, C., \& KIMBROUGH, D. 2009. Increasing the Self-Efficacy of Inservice Teachers through Content Knowledge. Teacher Education Quarterly, 36(2), 63-78.

SWAN, B. G., WOLF, K. J., \& CANO, J. 2011. Changes in Teacher Self-Efficacy from the Student Teaching Experience through the Third Year of Teaching. Journal Of Agricultural Education, 52(2), 128-139.

TABANCALI, E., \& ÇELIK, K. 2013. The relationship between academic selfefficacy and self-efficacy levels of teacher candidates. (English). International Journal Of Human Sciences, 10(1), 1167-1184.

WOODCOCK, S. 2011. A Cross Sectional Study of Pre-Service Teacher Efficacy throughout the Training Years. Australian Journal of Teacher Education, 36(10), 23-34.

YOST,D. S. 2006. Reflection and self-efficacy: Enhancing the retention of qualified teachersfrom a teacher education perspective. Teacher Education Quarterly, 33(4), 59-76. 